Jurnal Kesmas Asclepius

Volume 2, Nomor 1, Juni 2020

e-ISSN: 2684-8287

p-ISSN: 2656-8926

DOI: https://doi.org/10.31539/jka.v2i1.1139

\title{
TINGKAT PENGETAHUAN TERHADAP PENANGANAN PENYAKIT RHEUMATOID ARTHRITIS PADA LANSIA
}

\author{
Juli Andri ${ }^{1}$, Padila ${ }^{2}$, Andry Sartika $^{3}$, Selviyana Ega Nanang Putri ${ }^{4}$, \\ Harsismanto $\mathrm{J}^{5}$ \\ Universitas Muhammadiyah Bengkulu ${ }^{1,2,3,4,5}$ \\ juliandri@umb.ac.id ${ }^{1}$
}

\begin{abstract}
ABSTRAK
Penelitian ini bertujuan untuk mengetahui hubungan tingkat pengetahuan dengan penanganan penyakit rheumatoid arthritis pada lansia di BPPLU pagar dewa kota Bengkulu. Penelitian ini menggunakan metode observasional analitik dengan rancangan penelitian korelasi. Hasil analisis univariat yaitu terdapat 52\% lansia yang memiliki tingkat pengetahuan baik dan 52\% lansia memiliki penanganan penyaki rheumatoid artrhitis baik, sedangkan hasil analisis bivariat didapatkan nilai $\mathrm{P}=0.000$. Simpulan, terdapat hubungan antara tingkat pengetahuan dengan penanganan penyakit rheumatoid artrhitis pada lansia di Balai Pelayanan dan Penyantunan Lanjut Usia Pagar Dewa Kota Bengkulu.
\end{abstract}

Kata Kunci: Lansia, Rheumatoid arthritis, Tingkat Pengetahuan

\section{ABSTRACT}

This study aims to determine the relationship between the level of knowledge and the management of rheumatoid arthritis in the elderly in BPPLU Fence Dewa Bengkulu City. This study used an analytic observational method with a correlation study design. The results of the univariate analysis showed that 52\% of the elderly had a good level of knowledge and 52\% of the elderly had good management of rheumatoid arthritis, while the results of the bivariate analysis showed that the value of $P=0.000$. In conclusion, there is a relationship between the level of knowledge and the handling of rheumatoid arthritis in the elderly at the Pagar Dewa Elderly Service and Assistance Center, Bengkulu City.

Keywords: Elderly, Rheumatoid arthritis, Knowledge Level

\section{PENDAHULUAN}

Semakin pesatnya kemajuan ilmu pengetahuan dan perkembangan teknologi khususnya di bidang keperawatan gerontik manusia yang memasuki lanjut usia tentu pasti banyak pengalaman hidup tetapi memiliki sedikit kesempatan menikmati masa tua dengan layak dikarenakan telah terjadi penurunan kemampuan untuk mengurusi diri sendiri dan penyakit yang di timbulkan oleh proses penuaan (Fatimah, 2010; Padila, 2013). 
Di dunia semakin meningkat penyakit arthritis reumatoid pada lansia terutama banyak terjadi pada perempuan. Penelitian dari Mayo Clinic yang dilakukan di Amerika Serikat menunjukkan antara 1995-2005, wanita penderita Arthritis Reumatoid mencapai 54.000 - 100.000 orang, sedangkan pria hanya 29.000 dari 100.000 orang (Situmorong, 2017).

Rheumathoid Arthritis (RA) merupakan gangguan peradangan kronis autoimun atau respon autoimun, dimana imun seseorang bisa terganggu dan turun yang menyebabkan hancurnya organ sendi dan lapisan pada sinovial, terutama pada tangan, kaki dan lutut (Sakti \& Muhlisin, 2019; Masruroh \& Muhlisin, 2020). Sebagian besar masyarakat Indonesia menganggap remeh penyakit Rematik, karena sifatnya yang seolah-olah tidak menimbulkan kematian padahal rasa nyeri yang ditimbulkan sangat menghambat seseorang untuk melakukan aktivitas sehari-hari (Nurwulan, 2017). Penyakit Rematik sering kita dengar di masyarakat, Namun pemahaman yang benar tentang Rematik di keluarga belum memuaskan (Siahaan et al., 2017).

Angka kejadian rheumatoid arthritis pada tahun 2016 yang disampaikan oleh WHO adalah mencapai $20 \%$ dari penduduk dunia, 5-10\% adalah mereka yang berusia 5-20 tahun dan 20\% adalah mereka yang berusia 55 tahun (Majdah \& Ramli, 2016; Putri \& Priyanto, 2019).

Menurut Riskesdas (2018) jumlah penderita rheumatoid arthritis di Indonesia mencapai 7,30\%. Seiring bertambahnya jumlah penderita rheumatoid arthritis di Indonesia justru tingkat kesadaran dan salah pengertian tentang penyakit ini cukup tinggi. Keadaan inilah menjelaskan bahwa kurangnya pengetahuan masyarakat Indonesia khususnya penderita untuk mengenal lebih dalam lagi mengenai penyakit rheumatoid arthritis. Selanjutnya prevalensi yang terjadi di Jawa Tengah berjumlah $(6.78 \%)$.

Prevalensi berdasarkan diagnosis dokter tertinggi di Aceh (13,3\%). Prevalensi yang didiagnosa dokter lebih tinggi perempuan (8,5\%) dibanding dengan laki-laki 6,1\% (Riskesdas, 2018). Prevalensi jumlah penyakit di Jawa Tengah 25,5\% (Nurwulan, 2017). Prevalensi penyakit rematik berdasarkan diagnosis tenaga kesehatan atau gejala di kota Magelang 28,9\%, sedangkan di Kabupaten Magelang 11,7\% (Fajri \& Muhlisin, 2019).

Banyak orang menganggap rheumatoid arthritis sebagai radang sendi biasa, sehingga mereka terlambat melakukan pengobatan (Padila, 2013). Salah satu faktor yang mempengaruhi perilaku tentang penatalaksanaan rheumatoid arthritis adalah pengetahuan dan informasi. Pengetahuan merupakan hasil tahu yang terjadi setelah individu melakukan penginderaan terhadap suatu objek tertentu, dari pengalaman dan penelitian terbukti bahwa perilaku yang didasari oleh pengetahuan akan lebih bertahan dari pada perilaku yang tidak didasari oleh pengetahuan (Aklima et al., 2017).

Timbulnya nyeri membuat penderita seringkali takut untuk bergerak sehingga menganggu aktivitas sehari-hari dan dapat menurunkan produktivitasnya (Padila, 2012). Disamping itu, dengan mengalami nyeri, sudah cukup membuat pasien frustasi dalam menjalani hidupnya sehari-hari sehingga dapat menganggu kenyamanan pasien. Karenanya terapi utama yang diarahkan adalah untuk menangani nyeri ini (Lahemma, 2019). Dampak dari keadaan ini dapat mengancam jiwa penderitanya atau hanya menimbulkan gangguan kenyamanan dan masalah yang disebabkan oleh penyakit rematik tidak hanya berupa keterbatasan yang tampak jelas pada mobilitas hingga terjadi hal yang 
paling ditakuti yaitu menimbulkan kecacatan seperti kelumpuhan dan gangguan aktivitas hidup sehari-hari (Silaban, 2016).

Penanganan nyeri pada rematik dapat dilakukan dengan dua metode yaitu dengan farmakologi dan nonfarmakologi (Andri et al., 2019). Dengan farmakologi bisa menggunakan obatobatan analgesik, namun lansia pada proses penuaan mengalami farmakodinamik, farmakokinetik serta metabolisme obat dalam tubuh lansia sehingga sangat memberi resiko pada lansia. Selain itu efek yang dapat timbul dalam jangka panjang dapat mengakibatkan perdarahan pada saluran cerna, tukak peptik, perforasi dan gangguan ginjal (Mawarni \& Despiyadi, 2018).

Berdasarkan pengkajian dan wawancara yang dilakukan peneliti pada saat survey awal pada tanggal 03 Desember 2014 melalui 10 lansia diantarannya 5 perempuan dan 5 laki-laki didapatkan bahwa 5 dari 5 orang lansia perempuan di BPPLU mengalami rheumatoid arthritis, 3 diantaranya mengetahui cara penanganan penyakit rheumatoid arthritis serta 2 lainnya tidak mengetahui cara penanganan penyakit rheumatoid atritis sedangnkan dari 5 lansia laki-laki didapatkan 1 orang yang menderita rheumatoid atritis dan tidak mengetahui cara penanganan penyakit rheumatoid arthritis, dan didukung oleh data bahwa belum adanya penelitian sebelumnya yang dilakukan mengenai tingkat pengetahuan lansia dengan penanganan penyakit rheumatoid arhtritis di BPPLU ini.

\section{METODE PENELITIAN}

Dalam penelitian ini digunakan jenis penelitian observasional analitik dengan rancangan penelitian korelasi. Dimana rancangan penelitian ini digunakan untuk melihat hubungan tingkat pengetahuan perawatan lansia dengan kejadian reumatoid arthritis pada lansia di Balai Pelayanan dan Penyantunan Lanjut Usia Pagar Dewa Bengkulu.

Cara pengumpulan data diperoleh lansung dari subjek penelitian meliputi informasi mengenaai tingkat pengetahuan lansia dan dengan penanganan penyakit rheumatoid arthritis pada lansia di Balai Pelayanan dan Penyantunan Lanjut Usia Pagar Dewa Kota Bengkulu melalui pertanyaan yang diberikan.

\section{HASIL PENELITIAN}

Tabel. 1

Distribusi Frekuensi Responden terhadap Tingkat Pengetahuan Penyakit Rheumatoid Atritis

\begin{tabular}{clcc}
\hline No & \multicolumn{1}{c}{ Variabel } & N & $\%$ \\
\hline & Tingkat Pengetahuan Responden & & \\
1 & Baik & 13 & $52 \%$ \\
2 & Cukup Baik & 4 & $16 \%$ \\
3 & Kurang Baik & 8 & $32 \%$ \\
\hline \multicolumn{2}{r}{ Jumlah } & 25 & $100 \%$ \\
\hline
\end{tabular}

Berdasarkan tabel 1 disimpulkan bahwa hasil penelitian yang dilakukan terhadap 25 lanjut usia di BPPLU mayoritas lansia memiliki tingkat pengetahuan baik yaitu sebanyak 13 orang $(52 \%)$. 
Table. 2

Distribusi Frekuensi Responden terhadap Penanganan Penyakit Rheumatoid atritis

\begin{tabular}{|c|c|c|c|}
\hline No & Variabel & $\mathrm{N}$ & $\%$ \\
\hline & Penanganan Penyakit RA Responden & & \\
\hline 1 & Baik & 13 & $52 \%$ \\
\hline 2 & Cukup Baik & 5 & $20 \%$ \\
\hline 3 & Kurang Baik & 7 & $28 \%$ \\
\hline & Jumlah & 25 & $100 \%$ \\
\hline
\end{tabular}

Berdasarkan tabel 2 disimpulkan bahwa hasil penelitian yang dilakukan terhadap 25 lanjut usia di BPPLU mayoritas lansia penanganan penyakit rheumatoid atritisnya termasuk ke dalam kategori baik yaitu sebanyak 13 orang (52\%).

Table. 3

Distribusi Frekuensi Hubungan Tingkat Pengetahuan dengan Penanganan Penyakit Rheumatoid Atritis pada Lansia

\begin{tabular}{cccc}
\hline Variabel & $\mathrm{R}$ & $\mathrm{n}$ & P. Value \\
\hline Tingkat Pengetahuan & 0.904 & 25 & 0.000 \\
\hline
\end{tabular}

Berdasarkan tabel 3 dapat di lihat bahwa nilai korelasi tingkat pengetahuan dengan penanganan penyakit rheumatoid arthritis di dapat nilai $\mathrm{r}=0.904$ atau kekuatan hubungan sangat kuat, dan pola hubungan positif (+) yang artinya semakin tinggi tingkat pengetahuan responden maka semakin tinggi pula penanganan terhadap penyakit rheumatoid arthritis responden. Dan didapatkan pula p-value 0.000 artinya ada hubungan antara tingkat pengetahuan dengan penanganan penyakit rheumatoid arthritis pada lansia di Balai Pelayanan dan Penyantunan Lanjut Usia Pagar Dewa Kota Bengkulu.

\section{PEMBAHASAN}

\section{Pengetahuan Lansia tentang Rheumatoid Artrhitis}

Dari hasil penelitian dapat dilihat bahwa distribusi diketahui ada hubungan antara pengetahuan lansia penderita rheumatoid arthritis dengan penanganan penyakit rheumatoid arthritis didapatkan bahwa dari 25 lansia terdapat 8 orang (32\%) lansia dengan pengetahuan kurang baik, 4 orang (16\%) lansia dengan pengetahuan cukup baik, dan 13 orang $(52 \%)$ lansia berpengetahuan baik.

Hal ini sesuai dengan teori Notoadmojo (2014) yaitu pengetahuan atau kognitif merupakan domain yang sangat penting untuk terbentuknya tindakan seseorang. Pengetahuan yang baik tentang rheumatoid arthritis besar pengaruhnya terhadap tindakan penanganan penyakit rheumatoid arthritis yang dilakukan oleh lansia begitu juga sebaliknya, pengetahuan yang kurang akan mempengaruhi lansia untuk melakukan penanganan penyakit rheumatoid arthritis, jadi walaupun pengetahuan lansia masih banyak yang kurang tetapi masih dapat ditingkatkan dengan banyaknya informasi atau penyuluhan yang diberikan tentang penanganan penyakit rheumatoid arthritis. 
Faktor-faktor yang berhubungan dengan terjadinya rheumatoid arthritis menurut Ayumar \& Andi (2016) yaitu: umur, genetik, perilaku kesehatan, dan pengetahuan. Umur semakin bertambahnya umur, semakin tinggi resiko terkena rheumatoid arthritis. Setelah berusia 60 tahun keatas, resiko terjadi rheumatoid arthritis sangat mudah terkena. Rheumatoid arthritis yang diduga dipengaruhi oleh proses degeneratif. Genetik berperan penting terjadinya rheumatoid arthritis. Apabila ada anggota keluarga yang menderita rheumatoid arthritis, kemungkinan besar akan terkena rheumatoid arthritis.

Dari hasil uji korelasipun menunjukkan ada hubungan antara pengetahuan lansia penderita rheumatoid arthritis dengan penanganan penyakit rheumatoid arthritis, dimana didapatkan $\mathrm{p}$ value $0,000 \leq 0,05$. Dengan demikian hipotesis yang menyatakan ada ada hubungan tingkat pengetahuan dengan penanganan penyakit rheumatoid arthritis di Balai Pelayanan dan Penyantunan Lanjut Usia (BPPLU) Pagar Dewa Kota Bengkulu terbukti secara statistik.

\section{Penanganan Penyakit Rheumatoid Artrhitis}

Hasil penelitian menunjukkan bahwa dari 25 lansia, lebih banyak lansia yang cukup baik memahami cara penanganan penyakit rheumatoid arthritis. Menurut National Center for Chronic Disceasen Prevention and Health Promotion, persepsi pada masyarakat yang menyakini bahwa latihan dapat memperburuk sendi yang telah bengkak dan nyeri akibat rheumatoid arthritis, sangat keliru. Memang tidak bisa dipungkiri bahwa mereka yang terserang rheumatoid arthritis tentu harus memilih latihan yang sesuai dan ideal, yang agak berbeda bagi mereka yang sehat. Tingkat pengenalan dan pengetahuan rheumatoid arthritis memang masih dirasakan sangat kurang, baik pada masyarakat awam maupun kalangan medis.

Rhematoid arthritis diakibatkan adanya inflamasi kronik mengenai sendi-sendi sinovial seperti kemerahan, kekakuan sendi, dan pembengkakan. Proses terjadinya kerusakan sendi diakibatkan karena kartilago menjadi nekrosis. Bila kerusakan kartilago sangat luas maka terjadi adhesi diantara permukaan sendi, karena jaringan fibrosa dan tulang bersatu, kerusakan kartilago menyebabkan tendon dan ligamen menjadi lemah dan bisa menimbulkan sublokasi atau dislokasi dari persendian, invasi dari tulang bisa menyebabkan kerusakan sendi yang dapat menimbulkan gangguan nyeri pada penderita rematik (Siahaan et al., 2017).

Timbulnya nyeri membuat penderita seringkali takut untuk bergerak sehingga menganggu aktivitas sehari-hari dan dapat menurunkan produktivitasnya (Padila, 2012). Disamping itu, dengan mengalami nyeri, sudah cukup membuat pasien frustasi dalam menjalani hidupnya sehari-hari sehingga dapat menganggu kenyamanan pasien. Karenanya terapi utama yang diarahkan adalah untuk menangani nyeri ini (Lahemma, 2019).

Dampak dari keadaan ini dapat mengancam jiwa penderitanya atau hanya menimbulkan gangguan kenyamanan dan masalah yang disebabkan oleh penyakit rematik tidak hanya berupa keterbatasan yang tampak jelas pada mobilitas hingga terjadi hal yang paling ditakuti yaitu menimbulkan kecacatan seperti kelumpuhan dan gangguan aktivitas hidup sehari-hari (Silaban, 2016).

Menurut Ningsih (2012) tujuan utama dari program pengobatan adalah untuk menghilangkan nyeri dan peradangan, mempertahankan fungsi sendi dan kemampuan maksimal dari klien, serta mencegah dan/atau memperbaiki deformitas yang terjadi pada 
sendi. Penatalaksanaan yang sengaja dirancang untuk mencapai tujuan-tujuan itu meliputi pendidikan, istirahat, latihan fisik dan termoterapi, gizi, serta obat-obatan.

Penelitian yang dilakukan oleh Chintyawati (2017) hasil penelitian menunjukkan semua responden sebanyak 39 orang (100\%) pada pertanyaan mengenai mandi, berpakaian dan makan mempunyai tingkat kemandirian. Pertanyaan mengenai kebersihan diri dan berdiri dan jongkok di toilet sebagian besar responden 38 orang $(97,4 \%)$ cenderung mempunyai tingkat kemandirian dan sebanyak 1 orang $(2,6 \%)$ cenderung mempunyai tingkat ketergantungan di bantu.

\section{Hubungan Tingkat Pengetahuan Lansia dengan Penanganan Penyakit Rheumatoid Arthritis pada Lansia}

Berdasarkan uji kolerasi yang telah dilakukan pada penelitian ini dapat di lihat bahwa nilai korelasi tingkat pengetahuan dengan penanganan penyakit rheumatoid arthritis di dapat nilai $r=0.904$ atau kekuatan hubungan sangat kuat, dan pola hubungan positif (+) yang artinya semakin tinggi tingkat pengetahuan responden maka semakin tinggi pula penanganan terhadap penyakit rheumatoid arthritis responden. Dan didapatkan pula pvalue 0.000 yang artinya ada hubungan antara tingkat pengetahuan dengan penanganan penyakit rheumatoid arthritis pada lansia di Balai Pelayanan dan Penyantunan Lanjut Usia Pagar Dewa Kota Bengkulu.

Sejalan dengan penelitian yang dilakukan oleh Wibowo \& Zen (2017) dengan jenis penelitian yang digunakan adalah deskriptif korelasional dengan pendekatan cross sectional. Populasi dalam penelitian ini adalah kaluarga yang terdapat lansia dengan rheumatoid arthritis sebanyak 125 orang dengan menggunakan teknik pengambilan sampel secara purposive sampling hasil penelitian menunjukkan bahwa terdapat hubungan tingkat pengetahuan dengan sikap keluarga tentang perawatan rheumatoid arthritis pada lansia dengan p-value $=0,000$. Penelitian yang dilakukan Rany (2018) menyimpulkan bahwa perilaku lansia masih belum baik, dikarenakan pengetahuan yang informan miliki masih kurang hal tersebut dikarenakan pengetahuan yang acuh terhadap pelayanan kesehatan sehingga mengarah ke pencarian pengobatan sendiri dengan menggunakan jamu-jamuaan yang berdasarkan pengaruh budaya yang dimiliki lansia yang masih dipergunakan dalam pengobatan secara turun menurun.

Hal ini sesuai dengan pendapat Aklima et al., (2017) bahwa tingkat pengetahuan responden yang baik menghasilkan perilaku yang baik dalam menghadapi penyakit rheumatoid arthritis, misalnya dengan menjaga gerak, beban yang di angkat, menjauhi makanan yang mengandung tinggi purin seperti jeroan, daging dan kacang-kacangan, dan memeriksakan diri ke puskesmas atau dokter secara rutin (Ayu \& Muhlisin, 2020).

Sejalan dengan penelitian yang dilakukan Isrizal \& Lestari (2019) hasil penelitian ini menunjukkan sebagian besar responden memiliki pengetahuan baik sebanyak 16 orang $(53,3 \%)$ dan sebagian besar responden memiliki cara mengatasi nyeri arthritis rheumatoid baik sebanyak 22 orang $(73,3 \%)$. Ada hubungan pengetahuan terhadap cara mengatasi nyeri arthritis reumatoid pada lansia di Panti Tresna Werdha Budi Luhur di Kota Linggau Tahun $2019(\rho=0,022)$.

Dalam penelitiannya Isrizal \& Lestari (2019) juga berasumsi bahwa hubungan pengetahuan lansia dengan cara mengatasi nyeri reumatoid arthritis disebabkan oleh pengetahuan, apabila kita hubungkan dengan data umum, jika dilihat dari segi pengetahuan 
lansia yang baik tentang rheumatoid arthritis, maka ia dapat meningkatkan upaya penatalaksanaan terhadap penyakit tersebut. Dapat disimpulkan pengaruh pengetahuan lansia tentang reumatoid arthritis dengan cara mengatasi nyeri reumatoid arthritis yang dilakukan adalah berbanding lurus. Semakin rendah tingkat pengetahuan lansia tentang reumatoid arthritis semakin rendah pula cara mengatasi nyeri reumatoid arthritis yang dilakukannya dan sebaliknya, semakin tinggi tingkat pengetahuan lansia tentang reumatoid arthritis semakin tinggi pula cara mengatasi nyeri reumatoid arthritis yang dilakukan sehingga meningkatkan kualitas hidup lansia.

Pengetahuan merupakan dasar dari seseorang dalam melakukan tindakan. Sehingga tinggi rendahnya pengetahuan lansia penderita rheumatoid arthritis dengan penanganan penyakit rheumatoid arthritis sangat erat kaitannya dengan tingkat pengetahuan lansia.

Langkah pertama dari program penatalaksanaan rheumatoid arthritis adalah memberikan pendidikan kesehatan yang cukup tentang penyakit kepada klien, keluarga dan siapa saja yang berhubungan dengan klien. Pendidikan kesehatan yang diberikan meliputi pengertian tentang patofisiologi penyakit, penyebab penyakit, semua komponen program penatalaksanaan (Ningsih, 2012).

Menurut Senoaji \& Muhlisin (2017) pengetahuan akan mempengaruhi perilaku, dimana orang yang didasari olah pengetahuan akan langgeng melakukan suatu hal dari pada orang yang tanpa didasari oleh pengetahuan. Pengetahuan akan semakin baik jika dipraktikkan sehingga akan berdampak pada sikap dan perilaku (Muhlisin, 2016). Berdasarkan jurnal Septialti et al., (2017) pengetahuan berkaitan erat dengan tingkat pendidikan, hal tersebut berpengaruh erat dengan akses informasi, semakin tinggi pendidikan seseorang maka akses terhadap informasi juga semakin banyak.

Menurut Notoatmodjo (2014) bahwa sumber informasi yang diperoleh dari berbagai sumber maka seseorang cenderung mempunyai pengetahuan yang lebih luas. Informasi akan memberikan pengaruh pada pengetahuan seseorang, meskipun seseorang memiliki pendidikan yang rendah tetapi jika mendapatkan informasi yang baik dari berbagai sumber informasi (TV, radio, majalah, penyuluhan, smart phone dan lain-lain) maka akan meningkatkan pengetahuan seseorang.

Sumber informasi sangat mempengaruhi pengetahuan seseorang baik pemberi informasi maupun penerima, tetapi tergantung dari minat lansia untuk mencari informasi dari berbagai sumber baik dari majalah atau buku kesehatan, leaflet, koran, mengikuti perkumpulan atau penyuluhan tentang kesehatan. Pemberi informasi khususnya petugas kesehatan dalam menyampaikan informasi mengenai kesehatan akan mempengaruhi pengetahuan dan perubahan yang diterima oleh penderita apakah hal ini baik atau buruk untuk dilakukan (Popova et al., 2019).

\section{SIMPULAN}

Terdapat hubungan antara tingkat pengetahuan dengan penanganan penyakit rheumatoid arthritis di Balai Pelayanan dan Penyantunan Lanjut Usia Pagar Dewa Kota Bengkulu. 


\section{SARAN}

\section{Untuk BPPLU Pagar Dewa Kota Bengkulu}

Sebagai bahan informasi dan masukan data bagi BPPLU untuk mengetahui sejauh mana lanjut usia mengetahui tentang penyakit rheumatoid arthritis.

\section{Untuk Institusi Pendidikan Keperawatan}

Sebagai referensi untuk menambah wawasan yang berkaitan dengan mutu pelayanan keperawatan dan upaya peningkatan mutu pelayanan keperawatan. Serta memberikan masukan data untuk pengembangan ilmu, khususnya keperawatan gerontik.

\section{Untuk Peneliti Lain}

Dapat memberikan pengalaman awal dan pengetahuan dalam melakukan penelitian serta sebagai bahan dasar untuk penelitian selanjutnya.

\section{DAFTAR PUSTAKA}

Alkima, N., Safrida, S., \& Husin, M. D. (2017). Pengetahuan dan Sikap Manula tentang Penyakit Rematik di Kemukiman Lamlhom Kecamatan Lhoknga Kabupaten Aceh Besar. Jurnal Ilmiah Mahasiswa Fakultas Keguruan dan Ilmu Pendidikan Unsyiah, 2(3), 20-25

Andri, J., Karmila, R., Padila, P., Harsismanto, J., \& Sartika, A. (2019). Pengaruh Terapi Aktivitas Senam Ergonomis terhadap Peningkatan Kemampuan Fungsional Lansia. Journal of Telenursing (JOTING), 1(2), 304-313. https://doi.org/ https://doi.org/10.315 39/joting.v1i2.933

Ayu, S. M. T., \& Muhlisin, A. (2020). Gambaran Pengetahuan dan Perilaku tentang Penatalaksanaan Rheumatoid Arthtitis oleh Penderita di Desa Mancasan Wilayah Kerja Puskesmas Baki Sukoharj. Universitas Muhammadiyah Surakarta

Ayumar, A., \& Andi, Y. (2018). Faktor-Faktor yang Berhubungan dengan Kejadian Rheumatoid arthritis pada Lansia di Puskesmas Tompobulu Kabupaten Gowa. Jurnal Mitrasehat, VI(1)

Chintyawati, C. (2017). Hubungan antara Nyeri Reumatoid Arthritis dengan Kemandirian dalam Aktivitas Kehidupan Sehari-hari pada Lansia. (http: repository. Uinjkt.ac.id/dspace/handle/123456789/24157)

Fajri, A. N., \& Muhlisin, A. (2019). Gambaran Quality of Life pada Penderita Rheumatoid Arthritis di Komunitas. Universitas Muhammadiyah Surakarta

Fatimah, F. (2010). Merawat Manusia Lanjut Usia. Jakarta: Transinfo Media

Isrizal, I., \& Lestari, R. R. Y. (2019). Hubungan Pengetahuan terhadap Cara Mengatasi Nyeri Arthritis Reumatoid pada Lansia. Jurnal 'Aisyiyah Medika, 4(2), 256-264

Lahemma, A. (2019). Pengaruh Terapi Back Massage terhadap Penurunan Tingkat Nyeri Pada Penderita Rheumatoid Arthritis, 1-7

Majdah, Z., \& Ramli, N. (2016). Penanganan Rematik dengan Pemeriksaan LED, (May), $31-48$

Masruroh, A. N., \& Muhlisin, A. (2020). Gambaran Sikap dan Upaya Keluarga dalam Merawat Anggota Keluarga yang Menderita Rheumatoid Arthtritis di Desa Mancasan Wilayah Kerja Puskesmas Baki Kabupaten Sukoharjo. Universitas Muhammadiyah Surakarta 
Mawarni, T., \& Despiyadi, D. (2018). Pengaruh Pemberian Stimulus Kutaneus Slow Stroke Back Massage (SSBM) terhadap Penurunan Intensitas Nyeri Rematik pada Lansia di Panti Sosial Tahun 2018. Caring Nursing Journal, 2(2), 60-66

Muhlisin, A. (2016). Hubungan antara Fungsi Keluarga dengan Postpartum Blues pada Ibu Postpartum di Wilayah Kerya Puskesmat Tladan Kecamatan Kawedanan Kabupaten Magetan. Universitas Muhammadiyah Surakarta

Ningsih, N. (2012). Asuhan Keperawatan pada Klien dengan Gangguan Sistem Muskuloskeletal. Jakarta: Salemba Medika

Notoatmodjo, S. (2014). Ilmu Perilaku Kesehatan. Jakarta: Rineka Cipta

Nurwulan, E. (2017). Pengaruh Senam Rematik terhadap Tingkat Nyeri Sendi pada Lansia Penderita Rheumatoid Arthritis, 1-15

Padila, P. (2012). Buku Ajar Keperawatan Medikal Bedah. Yogyakarta: Nuha Medika

Padila, P. (2013). Asuhan Keperawatan Penyakit Dalam. Yogyakarta: Nuha Medika

Padila, P. (2013). Buku Ajar Keperawatan Gerontik. Yogyakarta: Nuha Medika

Popova, V., Vazhev, Z., Geneva-Popova, M., \& Batalov, A. (2019). Comparison of Rankl Expression, Inflammatory Markers, and Cardiovascular Risk in Patients with Acute Coronary Syndrome with and without Rheumatoid arthritis. Rheumatology International, 39(10), 1723-1732. https://doi.org/10.1007/s00296-019-04367-9

Putri, I. R. R., \& Priyanto, S. (2019). Penerapan Terapi Back Massage terhadap Penurunan Tingkat Nyeri pada Keluarga dengan Rheumatoid Arthritis. Universitas Muhammadiyah Magelang

Rany, N. (2018). Perilaku Lansia dalam Pengobatan Rheumatoid Arthritis (Rematik) di Kelurahan Pangkalan Kasai Kecamatan Seberida Kabupaten Indragiri Hulu. Jurnal Ilmu Kesehatan Masyarakat (Journal of Publik Health Sciences). 7(2), (htpp://jurnal.alinsyirah.ac.id/index. Php/kesmas)

Riskesdas. (2018). Hasil Utama Riset Kesehata Dasar (RISKESDAS) (Vol. 44, Issue 8). https://doi.org/10.1088/1751-8113/44/8/085201

Sakti, N. P. R., \& Muhlisin, A. (2019). Pengaruh Terapi Komplementer Meditasi terhadap Respon Nyeri pada Penderita Rheumathoid Arthtritis. The 9th University Research Colloqium (Urecol), 9(1)

Senoaji, A. U., \& Muhlisin, A. (2017). Hubungan Tingkat Pengetahuan Keluarga tentang Diit Hipertensi dan Tingkat Stres dengan Frekuensi Kekambuhan Hipertensi pada Lansia. Universitas Muhammadiyah Surakarta

Septialti, D., Marwani, A., Nugroho, D., \& Dharmawan, Y. (2017). Hubungan Pengatahuan Responden dan Faktor Demografi dengan Pernikahan Usia Dini di Kecamatan Banyumanik Tahun 2016. Jurnal Kesehatan Masyarakat, 5(4), 198 - 206

Siahaan, P., Siagian, N., \& Elon, Y. (2017). Efektivitas Pijat Punggung terhadap Intensitas Nyeri Rematik Sedang pada Wanita Lanjut Usia di Desa Karyawangi Kabupaten Bandung Barat. Jurnal Scolastik Keperawatan, 3(1), 53-58. https://doi.org/10.1073/pnas.94.23.12473

Silaban, N. Y. (2016). Gambaran Pengetahuan Penderita Rematik tentang Perawatan Nyeri Sendi di Dusun I Desa Sunggal Kanan Kecamatan Sunggal Kabupaten Deli Serdang Tahun 2015. Jurnal Ilmiah Keperawatan Imelda, 2(1), 46-55. https://doi.org/10.2411/jikeperawatan.v2i1.235 
Situmorang, S., \& Paskah, R. (2017). Gambaran Faktor - Faktor yang Mempengaruhi Pengetahuan Lansia terhadap Upaya Pencegahan Rhematoid Arthritis . Jurnal Ilmiah Keperawatan, 3(1). ojs.stikes-imelda. Imelda.ac.id/index.php/jilki/article/view/80

Wibowo, D. A., \& Zen, D. N. (2017). Hubungan Tingkat Pengetahuan dengan Sikap Keluarga tentang Perawatan Arthtitis Rheumatoid pada Lansia di Desa Pamalayan Kecamatan Cijeungjing Kabupaten Ciamis. Jurnal Kesehatan Bakti Tunas Husada, 17(2), 339-356 